\title{
Ex-situ conservation of the native orchid Coelogyne rochussenii de Vriese from the Bukit Rimbang and Baling Wildlife Reserve Areas
}

\author{
Pebra Heriansyah $^{1 *}$, Gusti Marlina ${ }^{1}$ \\ ${ }^{1}$ Department of Agrotechnology, Faculty of Agriculture, Universitas Islam Kuantan Singingi \\ Jl. Gatot Subroto KM 7, Teluk Kuantan, Riau, Indonesia. 29566 \\ *Email: hpebra92@gmail.com
}

\begin{abstract}
The native orchid Coelogyne rochussenii de Vriese is critically endangered, hence, conservative measures are needed to prevent extinction. Meanwhile, in-situ conservation is constrained by time, resources and costs. Therefore, this study aims to identify the most effective method for ex-situ conservation, especially with basal medium and activated charcoal, to determine the fastest germination. The completely randomized factorial design of four different basal media treatments including Knudson C, Vacin and Went, Murashige and Skoog, and Hyponex + vitamin medium were used. These treatments were combined with the application of activated charcoal at four different levels, with concentrations of $0,1,2$, and $3 \mathrm{~g} / \mathrm{L}^{-1}$, meanwhile, the parameters observed include germination day and percentage, as well as contamination percentage. The results showed that the conservation of native orchid C. rochussenii de Vriese using various growing media and activated charcoal had a significant effect on the growth of the embryo culture. Based on the results, the Hyponex + vitamin medium with $3 \mathrm{~g} / \mathrm{L}^{-1}$ accelerated germination days to 29.33 , increased germination percentage to $92.06 \%$, and reduced contamination to $0 \%$.
\end{abstract}

Keywords: activated charcoal; basal medium; completely randomized factorial design; orchid conservation; tissues culture

\footnotetext{
Article History: Received 20 February 2021; Received in revised form 6 May 2021; Accepted 30 May 2021; Available online 30 June 2021

How to Cite This Article: Heriansyah P, Marlina G. 2021. Ex-situ conservation of the native orchid Coelogyne rochussenii de Vriese from the Bukit Rimbang and Baling Wildlife Reserve Areas. Biogenesis: Jurnal Ilmiah Biologi. vol 9(1): 102-108. doi: https://doi.org/10.24252/bio.v9i1.21274.
}

\section{INTRODUCTION}

The orchid Coelogyne rochussenii de Vriese is a widely distributed plant across Southern Thailand, Peninsular Malaysia, Singapore, Kalimantan, Sumatra, and Java Island, Sulawesi, Maluku, and Palawan in the Philippines (Lok et al., 2011).

Native orchids are threatened with extinction both locally and globally, this condition is triggered by the plundering of the plants for commercial purposes (Ticktin et al., 2020). The trade of protected species in 2015 reached 7000 cases in the world (UNODC, 2016), while illegal logging and forest land conversion from 2000 to 2010 was up to 6.6 Mha in Indonesia, particularly in Kalimantan, Sumatra, Papua, Sulawesi, and Maluku (Abood et al., 2015). In addition, native orchid extinctions are also caused by the dependence of the plant on mycorrhizal fungi and insect pollinators which are disturbed by the imbalance in the ecosystem (Kolanowska et al., 2020).

The habitat of this plant has also been eroded by the increasingly disrupted forest conditions. There is degradation of the buffer areas in the Bukit Rimbang and Baling Wildlife Reserve areas up to $82.25 \%$ (Suandy et al., 2014), therefore, conservative measures are needed to prevent orchids from extinction.

Conservation is a strategic measure to save the orchid $C$. rochussenii de Vriese from extinction locally. This is carried out by saving existing genetic resources, which are then reintroduced into the habitat (Crouzeilles et al., 2021). Furthermore, conservation is performed in two ways namely in-situ and ex-situ. In-situ conservation produces great results but it is time-consuming and resource-intensive, hence, the most effective method is ex-situ (Leclère $e t$ al., 2020).

Ex-situ conservation of orchids is carried out using tissue culture techniques (Lin et al., 2020). This technique was chosen because it has many advantages compared to conventional techniques (Agrawal et al., 2019; Ayuso et al., 2019; Muñoz et al., 2019; Streczynski et al., 2019) and produces plant seeds in large quantities within a short time (Heriansyah \& Marlina, 2021). The in-vitro conservation of $C$. 
rochussenii orchid is influenced by various factors, including the type of explants used in tissue culture techniques. Besides, the use of explants depends on the number of orchid populations in the habitat. Hence, there is a need to consider the type of explants used. Potential explants include the use of seeds (Utami \& Hariyanto, 2019) as previously studied by Adhikari \& Pant (2019), Dulić et al. (2019), Godo et al. (2020), and Manokari et al. (2021). However, this study differs from previous studies, we provided $C$. rochussenii orchid seeds taken directly from the wildlife reserve area of Bukit Rimbang and Baling wildlife reserve areas.

Embryo growth in orchid seed culture is strongly influenced by the type of medium used (Barrientos \& Fang, 2019), each orchid has a different response to medium formulations. The Knudson $\mathrm{C}$ (KC) medium is more suitable for planting $C$. ovalis Lindl (Singh \& Kumaria, 2020), while Murashige and Skoog (MS) medium is more suitable for Dendrobium officinale orchids (Gao et al., 2020), and Gastrochilus matsuran (Makino) Schltr (Kang et al., 2020). Furthermore, the Vacin and Went medium is more suitable for planting Phalaenopsis amboinensis JJ Sm orchid (Utami $\&$ Hariyanto, 2019). Therefore, there is need to determine the most suitable media for $C$. rochussenii orchids seed culture.

The germination of seeds via in-vitro propagation is still low with a range of $30-45 \%$, meanwhile, the germination percentage is influenced by the presence of light in the medium (Sorgato et al., 2020). Besides, the various types of orchids respond differently to the percentage of light in the media, hence, it is necessary to add a light-reducing ingredient in the form of activated charcoal. A previous study reported that the addition of activated charcoal produced a good effect on the germination percentage (Kim et al., 2019). Therefore, this study aims to determine the best basal medium and concentration of activated charcoal for conservation of native orchids $C$. rochussenii de Vriese from Bukit Rimbang and Baling Wildlife Reserves Areas.

\section{MATERIALS AND METHODS}

Plant collection. The adult orchid capsules (Coelogyne rochussenii de Vriese) were collected from Bukit Rimbang and Baling Wildlife Reserves Area at coordinate points $00^{\circ} 18 ' 59.61 " \mathrm{~S} 101^{\circ} 11^{\prime} 03.75$ "E, elevation $92 \mathrm{~m}$ above sea level. The capsules were dried at $280^{\circ} \mathrm{C}$ for $48 \mathrm{~h}$ to remove excess moisture, placed in a petri dish on a silica gel base and kept at $40^{\circ} \mathrm{C}$ in continuous darkness until use. The collection protocol was following our previous studies (Heriansyah \& Marlina, 2021).

Capsule sterilization. After a storage period of 1 day, the capsule surface was sterilized with $7 \%(\mathrm{w} / \mathrm{v})$ calcium hypochlorite containing $0.1 \% \quad(\mathrm{v} / \mathrm{v})$ Tween 20 (Acros Organics, Geel, Belgium) for $20 \mathrm{~min}$. The seeds were further rinsed with distilled water three times, sterilized in a laminar flow hood with $70 \%$ (v/v) ethanol for $2 \mathrm{~min}$, and then rinsed three times in sterile distilled water (Vasil, 1984; Bello et al., 2018).

The treatment of various basal media and the addition of activated charcoal. To evaluate the optimal medium composition for germination, four basal media were used including Knudson $\mathrm{C}(\mathrm{KC})$, Vacin and Went (VW), Murashige and Skoog (MS), and Hyponex + vitamin medium (Oktafiani et al., 2011). This treatment was combined with the addition of activated charcoal at four different levels of $0,1,2$, and $3 \mathrm{~g} / \mathrm{L}^{-1}$. All tested media contained $2 \%(\mathrm{w} / \mathrm{v})$ sucrose, $7 \%(\mathrm{w} / \mathrm{v})$ agar (Biolife Italiana), while the $\mathrm{pH}$ of all medium was adjusted to $5.80 \pm 0.02$ with $0.1 \mathrm{M} \mathrm{HCl}$ or $0.1 \mathrm{M} \mathrm{NaOH}$. Furthermore, the medium was heated to $100^{\circ} \mathrm{C}$ and then placed into a culture glass with a thickness of $2 \mathrm{~cm}$ and then covered with aluminum foil and plastic. The media was then autoclaved at $121^{\circ} \mathrm{C}$ for $20 \mathrm{~min}$, and stored in the culture room until the seeds were ready for planting.

Planting explants. The sterilized capsules in a laminar airflow cabinet were placed in a petri dish, split using a scalpel, sprinkled into a sterilized solid media and stored for one week. After sowing the seeds, the medium was then covered with aluminum foil and plastic, stored at $23 \pm 20^{\circ} \mathrm{C}$ with a light photoperiod of $16 \mathrm{~h}$, while $40 \mu \mathrm{mol} \mathrm{m} \mathrm{m}^{-2} \mathrm{~s}^{-1}$ photosynthetically active 
radiation (PAR) was provided by a white fluorescent lamp (Philips, Saint-Priest, France) (McKendrick, 2000).

Observations. The embryo culture results were observed before subculturing, given that the parameters of leaves, stems, and roots are not observable after subculturing due to the small size of the embryo. Therefore, the following parameters were observed including germination day (day) and percentage (\%), and contamination percentage $(\%)$. The embryos were also observed using a microscope.

Data analysis. Data processing and statistical analysis were performed on the data observed in this study. The data obtained were analyzed using ANOVA and the mean values were separated using Tukey's HSD test at 5\% level. All data analysis were performed with SPSS version 26 (IBM Corp., Armonk, New York, USA).

\section{RESULTS AND DISCUSSION}

Germination day. The fastest germination day (29.33) was found in the Hyponex + vitamin medium combined with $3 \mathrm{~g} / \mathrm{L}^{-1}$ activated charcoal media. Furthermore, the combination of activated charcoal with Knudson C (KC), Vacin \& Went (VW), and Murashige \& Skoog (MS) media, showed that the $3 \mathrm{~g} / \mathrm{L}^{-1}$ activated charcoal concentration produced the fastest germination compared to the control (Fig. 1).

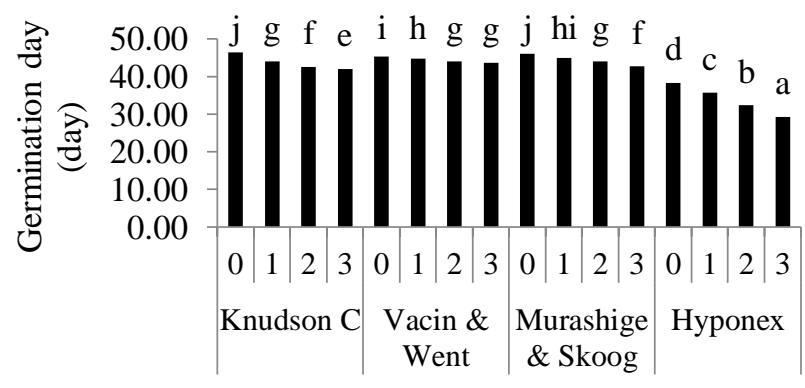

Fig. 1. The effect of various media and activated charcoal with concentrations of $0,1,2$, and $3 \mathrm{~g} \mathrm{~L}-1$ on germination day of Coelogyne rochussenii De Vriese. Different letters indicate significant differences according to Tukey's HSD $(\mathrm{P}<0.05)$ test.

Observations on the germination day of the C. rochussenii de Vriese orchid are presented in Fig. 1. Hyponex medium has a very simple compound similarly provided by the plant's natural habitat. Meanwhile, the most important factor needed for embryo development is the water content in the medium. Compared to Puspitaningtyas \& Handini (2014), this study obtained different results, thus the growth regulators used in the initial medium were not added. Furthermore, the $3 \mathrm{~g} / \mathrm{L}^{-1}$ activated charcoal concentration produced the fastest germination, because activated charcoal reduces light in the medium. This is in line with Kim et al. (2019) that light affects the speed of plant germination.

Percentage of germination. The highest germination percentage $(92.06 \%)$ was found in the Hyponex + vitamin medium combined with $3 \mathrm{~g} / \mathrm{L}^{-1}$ activated charcoal. Furthermore, the combination of activated charcoal with $\mathrm{KC}$, VW, and MS medium showed higher yields. The $3 \mathrm{~g} / \mathrm{L}-1$ activated charcoal concentration produced the highest germination percentage (Fig. 2)

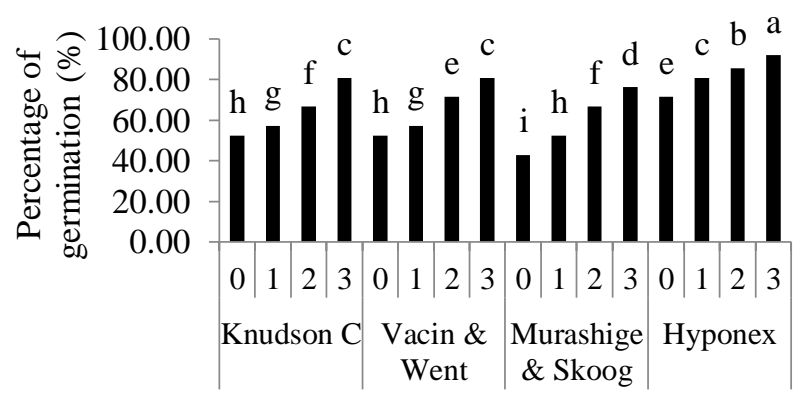

Fig. 2. Percentage yield of germination with various medium treatments and activated charcoal concentration. The same capital or non-capital letters in the same diagram show no significant difference according to the honest real difference test (Tukey test) at the level 5\%.

The Hyponex medium treatment produced the best germination percentage because this medium effectively supports orchid embryo germination. In line with Ren (2020) which reported that Hyponex medium containing simple nutrients in the form of $\mathrm{N}, \mathrm{P}$, and $\mathrm{K}$ supports Paphiopedilum wardii growth. Furthermore, the $3 \mathrm{~g} / \mathrm{L}^{-1}$ activated charcoal concentration produced the highest germination percentage due to the limited light provided to the medium. According to Sorgato et al. (2020), germination was accelerated under light limitation on the medium. The development stages of $C$. rochussenii de Vriese with four basal media are visualized in Fig. 3 . 


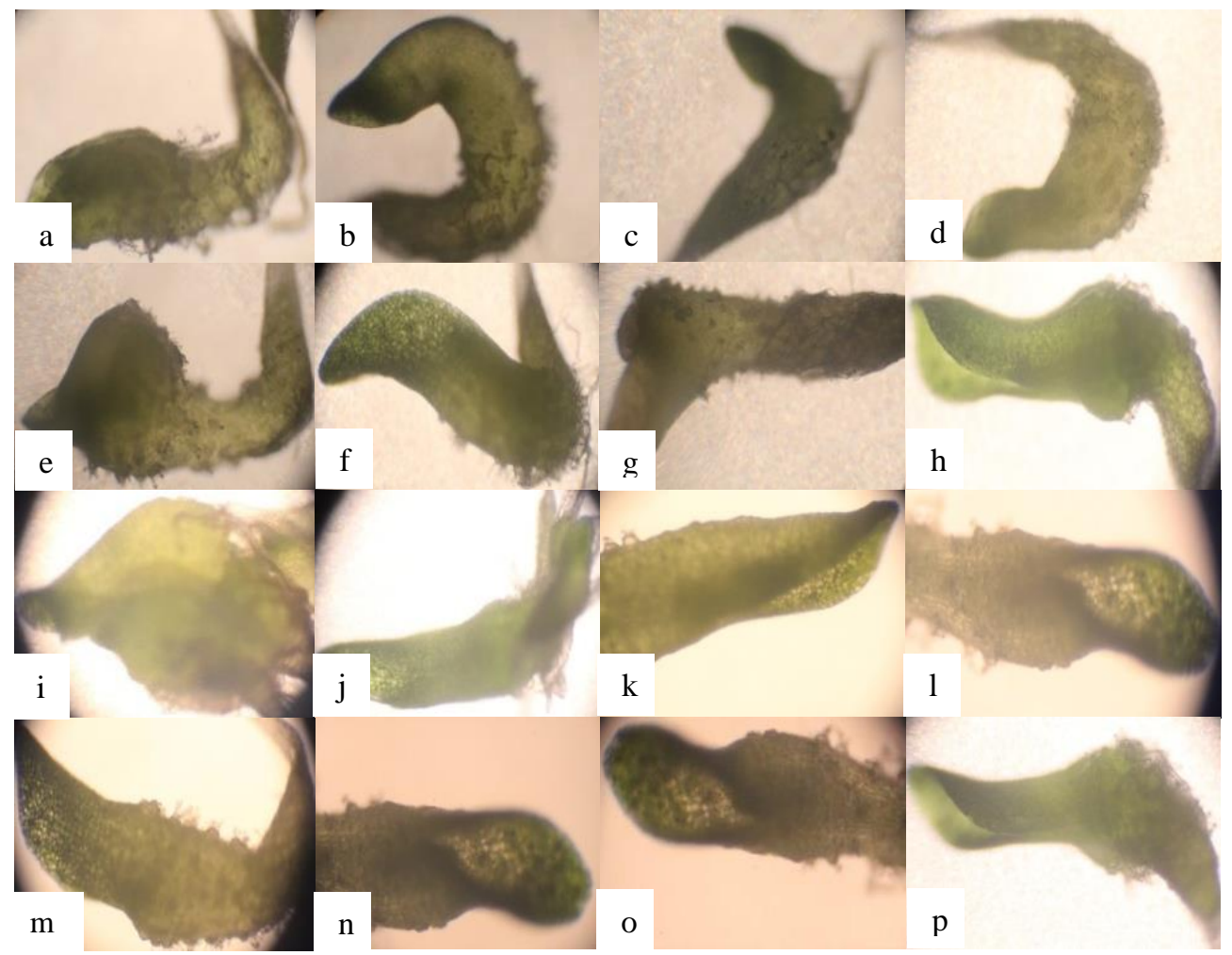

Fig. 3. Development stages of Coelogyne rochussenii de Vriese with various basal media: a-d. Knudson C; e-h. Vacin and Went; i-l. Murashige and Skoog; m-p. Hyponex + vitamin. Each treatment was combined with the addition of activated charcoal sequentially $\left(0,1,2\right.$, and $\left.3 \mathrm{~g} / \mathrm{L}^{-1}\right)$.

Percentage of contamination. The lowest contamination percentage $(0 \%)$ was found in the Hyponex + vitamin medium combined with $3 \mathrm{~g} / \mathrm{L}^{-1}$ activated charcoal. Furthermore, the combination of activated charcoal with $\mathrm{KC}$, VW, and MS media showed that the $3 \mathrm{~g} / \mathrm{L}^{-1}$ activated charcoal concentration produced the lowest contamination percentage (Fig. 4).

The Hyponex medium treatment produced the lowest percentage of contamination. The addition of Hyponex required a short time, hence, suppressing the opportunity for contaminants to enter the culture medium. Meanwhile, a longer time is needed in other media to weigh and insert the stock solution sequentially, thereby providing opportunities for the entry of contaminants. The technique for making a medium affects the level of contamination of explants, the longer the medium container is open, creating air currents, the greater the possibility of contamination (Sanders, 2012; Prihastanti et al., 2020). Furthermore, treatment with activated charcoal produced a significant effect on the percentage of contamination, with the lowest percentage found at a concentration of $3 \mathrm{~g} / \mathrm{L}^{-1}$. Activated charcoal is an absorbent, plays a role in absorbing contaminants. The activated charcoal in the media acts as an absorbent, absorbs contaminants as well as exudates released by explants, and improve growth and development (Prizão et al., 2012; Warakagoda \& Subasinghe, 2013).

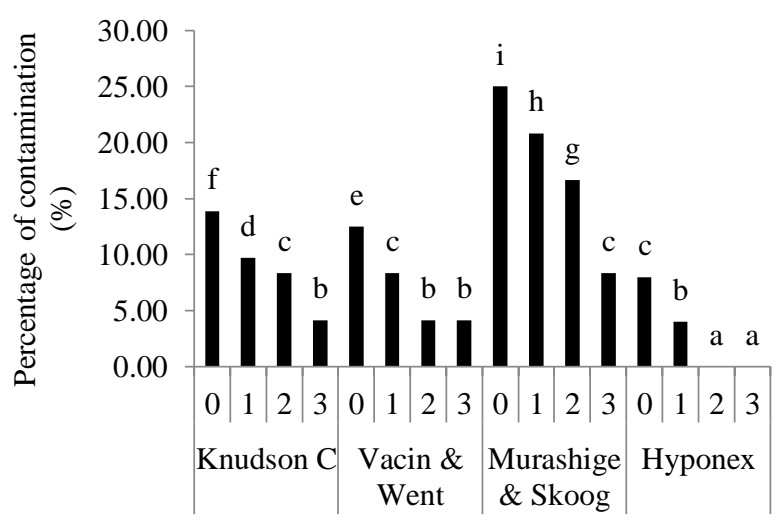

Fig. 4. Average percentage of contamination with various medium treatments and activated charcoal concentration. The same capital or non-capital letters in the same diagram show no significant difference according to the honest real difference test (Tukey test) at the level $=5 \%$. 
Based on QS. Al-Mulk verse 3 (Kementerian Agama RI, 2019a), Allah swt created the earth and everything in it in a balanced state. The balance shows that the components of the ecosystem are perfectly regulated by Allah swt. However, damages to forests which lead to the potential extinction of organisms is caused by human activities. An example of plant which is critically endangered is orchid due to logging and looting activities carried out by humans, according to Allah QS Ar-Rum verse 41 (Kementerian Agama RI, $2019 b$ ) which says, it is human hands that cause destruction on Earth.

Humans appointed by Allah swt as Khalifah (leader) on earth need to pay attention to Allah's prohibition in QS Al-Qashash verse 77 (Kementerian Agama RI, 2019c) which forbids humans from causing damage to the earth, including carrying out logging and looting activities which leads to the potential extinction of orchids in the forest. Furthermore, humans as Khalifah have an obligation to maintain and restore the balance of nature, in other words, humans are obliged to carry out conservation measures to prevent the extinction of organisms on earth.

\section{CONCLUSION}

The conservation of the native orchid Coelogyne rochussenii de Vriese using various growing media and activated charcoal had a significant effect on the growth of the embryo culture. The Hyponex + vitamin medium with 3 $\mathrm{g} / \mathrm{L}^{-1}$ accelerated germination days to 29.33 , increased germination percentage to $92.06 \%$, and reduced contamination to $0 \%$.

\section{ACKNOWLEDGEMENTS}

This study was funded by Beginner Lecturer Research Grand from Ministry of Research and Technology/National Research and Innovation Agency, Republic Indonesia with the contract number of 079/LL10/PG /2019.

\section{REFERENCES}

Abood SA, Lee JSH, Burivalova Z, Garcia-Ulloa J, Koh LP. 2015. Relative contributions of the logging, fiber, oil palm, and mining industries to forest loss in Indonesia. Conservation Letters. vol 8(1): 58-67. doi: https://doi.org/10.1111/conl.12103

Adhikari H, Pant B. 2019. Effect of 6-benzylaminopurine and-naphthalene acetic acid hormonal supplements on the in vitro seed germination and seedling development of orchid Otochilus albus Lindl. African Journal of Biotechnology. vol 18(22): 472477. doi: https://doi.org/10.5897/AJB2019.16774.

Agrawal A, Singh S, Malhotra EV, Meena DPS, Tyagi RK. 2019. In vitro conservation and cryopreservation of clonally propagated horticultural species. Conservation and utilization of horticultural genetic resources. Singapore: Springer. pp. 529-578.

Ayuso M, García-Pérez P, Ramil-Rego P, Gallego PP, Barreal ME. 2019. In vitro culture of the endangered plant Eryngium viviparum as dual strategy for its ex situ conservation and source of bioactive compounds. Plant Cell, Tissue and Organ Culture (PCTOC). vol 138(3): 427-435. doi: https://doi.org/10.1007/s11240-019-01638-y.

Barrientos BAB, Fang JY. 2019. Influence of photoperiod and culture medium on the speed of asymbiotic seed germination and seedling development in Spathoglottis plicata. HortScience. vol 54(9): 1570-1575. doi: https://doi.org/10.21273/HORTSCI14214-19.

Bello OA, Esan EB, Obembe OO. 2018. Establishing surface sterilization protocol for nodal culture of Solanecio biafrae. IOP Conference Series: Earth and Environmental Science. vol 210(1): 1-6. doi: https://doi.org/10.1088/1755-1315/210/1/012007.

Crouzeilles R, Maurenza D, Prieto PV, Barros FS, Jakovac C, Ferreira MS, Chazdon RL, Lindenmayer DB, Brancalion PHS, Ceccon E, Adams C, LazosChavero E, Monteiro L, Junqueira AB, Strassburg BBN, Guariguata MR. 2021. Associations between socio-environmental factors and landscape-scale biodiversity recovery in naturally regenerating tropical and subtropical forests. Conservation Letters. $\quad$ vol 14(2): 1-9. doi: https://doi.org/10.1111/conl.12768.

Dulić J, Ljubojević M, Ognjanov V, Barać G, Dulić T. 2019. In vitro germination and seedling development of two European orchid species, Himantoglossum jankae Somlyay, Kreutz \& Óvári and Spiranthes spiralis (L.) Chevall. In Vitro Cellular \& Developmental Biology-Plant. vol 55(4): 380-391. doi: https://doi.org/10.1007/s11627-019-09997-z.

Gao H, Xu D, Zhang H, Cheng X, Yang Q. 2020. Effects of culture medium composition and PEG on hyperhydricity in Dendrobium officinale. In Vitro Cellular \& Developmental Biology-Plant. vol 56(2): 143-149. doi: https://doi.org/10.1007/s11627-020-10075-y.

Godo T, Hashimoto T, Nakata M, Miyoshi K. 2020. The effects of illumination, temperature and 6benzylaminoprine on asymbiotic seed germination and protocorm development in vitro in the achlorophyllous orchid Gastrodia pubilabiata 
Sawa. In Vitro Cellular \& Developmental Biology. vol 56(2): 230-235. doi: https://doi.org/10.1007/s11627-020-10061-4.

Heriansyah P, Marlina G. 2021. Characterization and potential of Coelogyne rochussenii orchids from Bukit Rimbang and Bukit Baling Wildlife Sanctuary as explant source. Jurnal Sylva Lestari. vol 9(1): 64-75. doi: http://dx.doi.org/10.23960/js11964-75.

Kang H, Kang KW, Kim DH, Sivanesan I. 2020. In vitro propagation of Gastrochilus matsuran (Makino) Schltr., an endangered epiphytic orchid. Plants. vol 9(4): 1-10. doi: https://doi.org/10.3390/plants9040524.

Kementerian Agama RI. 2019a. Terjemahan Al Qur'an Surat Al-Mulk ayat 3. https://quran.kemenag.go.id/.

Kementerian Agama RI. 2019b. Terjemahan Al Qur'an Surat Ar-Rum ayat 41. https://quran.kemenag.go.id/.

Kementerian Agama RI. 2019c. Terjemahan Al Qur'an Surat Al-Qashash 77 ayat https://quran.kemenag.go.id/.

Kim DH, Kang KW, Enkhtaivan G, Jan U, Sivanesan I. 2019. Impact of activated charcoal, culture medium strength and thidiazuron on non-symbiotic in vitro seed germination of Pecteilis radiata (Thunb.) Raf. South African Journal of Botany. vol 124: 144-150. doi: https://doi.org/10.1016/j.sajb.2019.04.015.

Kolanowska M, Rewicz A, Baranow P. 2020. Ecological niche modeling of the pantropical orchid Polystachya concreta (Orchidaceae) and its response to climate change. Scientific Reports. vol 10(1): 1-17. doi: https://doi.org/10.1038/s41598020-71732-1.

Leclère $D$, Obersteiner $M$, Barrett $M$, Butchart SH, Chaudhary A, De Palma A, DeClerck FAH, Marco MD, Doelman JC, Dürauer M, Freeman R, Harfoot M, Hasegawa T, Hellweg S, Hilbers JP, Hill SLL, Humpenöder F, Jennings N, Krisztin T, Mace GM, Ohashi H, Popp A, Purvis A, Schipper AM, Tabeau $A$, Valin H, van Meijl H, van Zeist WJ, Visconti P, Alkemade R, Almond R, Bunting G, Burgess ND, Cornell WE, Fulvio FD, Ferrier S, Fritz S, Fujimori S, Grooten M, Harwood T, Havlík P, Herrero M, Hoskins AJ, Jung M, Kram T, Lotze-Campen H, Matsui T, Meyer C, Nel D, Newbold T, SchmidtTraub G, Stehfest E, Strassburg BBN, van Vuuren DP, Ware C, Watson JEM, Wu W, Young L. 2020. Bending the curve of terrestrial biodiversity needs an integrated strategy. Nature. vol 585(7826): 551556. doi: https://doi.org/10.1038/s41586-020-2705y.

Lin W, Wang J, Xu X, Wu Y, Qiu D, He B, Sarsaiya S, Ma X, Chen J. 2020. Rapid propagation in vitro and accumulation of active substances of endangered Dendrobium cariniferum Rchb. f. Bioengineered. vol 11(1): 386-396. doi: https://doi.org/10.1080/21655979.2020.1739406.

Lok AFSL, Ang WF, Chong KY, Yeo CK, Tan HTW. 2011. Rediscovery in Singapore of Coelogyne rochussenii de Vriese (Orchidaceae). Nature in Singapore. vol 4: 49-53.

Manokari M, Latha R, Priyadharshini S, Jogam P, Shekhawat MS. 2021. Short-term cold storage of encapsulated somatic embryos and retrieval of plantlets in grey orchid (Vanda tessellata (Roxb.) Hook. ex G. Don). Plant Cell, Tissue and Organ Culture (PCTOC). vol 144(1): 171-183. doi: https://doi.org/10.1007/s11240-020-01899-y.

McKendrick S. 2000. In vitro germination of orchids: a manual. Madison: Ceiba Foundation for Tropical Conservation. pp. 1-17. https://ceiba.org/.

Muñoz M, Díaz O, Reinún W, Winkler A, Quevedo R. 2019. Slow growth in vitro culture for conservation of Chilotanum potato germplasm. Chilean Journal of Agricultural Research. vol 79(1): 26-35. doi: http://dx.doi.org/10.4067/S071858392019000100026.

Oktafiani A, Puspitasari M, Purbiati T, Destiwarni D. 2011. Pengaruh beberapa media kultur jaringan terhadap pertumbuhan planlet anggrek Phalaenopsis bellina. Pontianak: Balai Pengkajian Teknologi Pertanian Kalimantan Barat. https://kalbar.litbang.pertanian.go.id/.

Prihastanti E, Hastuti ED, Suedy SWA. 2020. Comparing the growth of stem explants between Citrus reticulata var. Tawangmangu and $C$. reticulata var. Garut using in vitro culture methods. Biodiversitas Journal of Biological Diversity. vol 21(12): 58455849.

doi: https://doi.org/10.13057/biodiv/d211248.

Prizão EC, Gonçalves LDM, Gutierre MAM, Mangolin CA, Machado MDFPDS. 2012. Activated charcoal and graphite for the micropropagation of Cattleya bicolor Lindl. and a orchid double-hybrid 'BLC Pastoral Innocence'. Acta Scientiarum. vol 34(2): 157-161.

doi: https://doi.org/10.4025/actasciagron.v34i2.12257.

Puspitaningtyas DM, Handini E. 2014. Penyimpanan biji anggrek Coelogyne spp. untuk konservasi ex situ. Buletin Kebun Raya. vol 17(2): 101-112.

Ren H. 2020. Conservation and Reintroduction of Rare and Endangered Plants in China. Singapore: Springer. p 233. https://doi.org/10.1007/978-98115-5301-1.

Sanders ER. 2012. Aseptic laboratory techniques: plating methods. JoVE (Journal of Visualized Experiments). vol (63): 1-18. doi: https://dx.doi.org/10.3791\%2F3064.

Singh N, Kumaria S. 2020. A combinational phytomolecular-mediated assessment in micropropagated plantlets of Coelogyne ovalis Lindl.: a horticultural and medicinal Orchid. Proceedings of the National Academy of Sciences, India Section B: Biological Sciences. vol 90(2): 455-466. doi: https://doi.org/10.1007/s40011-01901118-5.

Sorgato JC, Soares JS, Damiani CR, Ribeiro LM. 2020. Effects of light, agar, activated charcoal, and culture medium on the germination and early development 
of' Dendrobium' seedlings. Australian Journal of Crop Science. vol 14(4): 557-564.

Streczynski R, Clark H, Whelehan LM, Ang ST, Hardstaff LK, Funnekotter B, Bunn E, Offord CA, Sommerville KD, Mancera RL. 2019. Current issues in plant cryopreservation and importance for ex situ conservation of threatened Australian native species. Australian Journal of Botany. vol 67(1): 115. doi: https://doi.org/10.1071/BT18147.

Suandy I, Mulyadi A, Moersidik SS, Suganda E. 2014. Degradasi lingkungan di kawasan penyangga Suaka Margasatwa Bukit Rimbang Bukit Baling Propinsi Riau. Jurnal Ilmu Lingkungan. vol 8(2): 214-225.

Ticktin T, Mondragón D, Lopez-Toledo L, Dutra-Elliott D, Aguirre-León E, Hernández-Apolinar M. 2020. Synthesis of wild orchid trade and demography provides new insight on conservation strategies. Conservation Letters. vol 13(2): 1-10. doi: https://doi.org/10.1111/conl.12697.

UNODC. 2016. World drug report. New York: United Nations Office on Drugs and Crime. p 174. https://www.unodc.org/.

Utami ESW, Hariyanto S. 2019. In vitro seed germination and seedling development of a rare Indonesian native orchid Phalaenopsis amboinensis JJ Sm. Scientifica. vol 2019: 1-6. doi: https://doi.org/10.1155/2019/8105138.

Vasil IK. 1984. Cell culture and somatic cell genetics of plants, vol 1, laboratory procedures and their applications. London: Academic Press, inc.

Warakagoda PS, Subasinghe S. 2013. In vitro propagation of Pterocarpus santalinus L. (Red Sandalwood) through tissue culture. Journal of the National Science Foundation of Sri Lanka. vol 41(1): 53-63. 